\title{
HABELOS, HAINOS. DETECCIÓN REMOTA DE INDI- CIOS ARQUEOLÓXICOS MEDIANTE FOTOGRAFÍA AÉREA E LIDAR EN CASTROS DE GALICIA*
}

\author{
CÉSAR PARCERO-OUBiÑA \\ Instituto de Ciencias del Patrimonio (CSIC) \\ ORCID iD: http://orcid.org/0000-0003-3000-4232
}

\begin{abstract}
* Dispoñibilidade de datos depositados: unha capa vectorial coa totalidade dos elementos identificados ate a data está dispoñible en Digital CSIC, na seguinte dirección: $<$ http://hdl.handle. net/10261/210565>. Para cada elemento a capa inclúe información acerca da/s fonte/s na/s que foi identificado. Nese mesmo sitio pode atoparse unha versión en cores e alta resolución de tódalas figuras do artigo.

*Agradecementos: Agradezo de xeito especial a Ignacio Vilaseco, técnico da Dirección Xeral de Patrimonio, a súa dispoñibilidade para comprobar a existencia dos sitios descubertos no Inventario Arqueolóxico de Galicia.
\end{abstract}

Copyright: (C) 2021 CSIC. La edición electrónica de esta revista se distribuye bajo los términos de una licencia de uso y distribución Creative Commons Reconocimiento 4.0 Internacional (CC BY 4.0).

Cómo citar/Citation: César PARCERO-OuBIÑA, "Habelos, hainos. Detección remota de indicios arqueolóxicos mediante fotografía aérea e Lidar en castros de Galicia", Cuadernos de Estudios Gallegos, 68, núm. 134 (2021), págs. 15-45, https://doi.org/10.3989/ceg.2021.134.01 


\section{HABELOS, HAINOS. DETECCIÓN REMOTA DE INDICIOS ARQUEOLÓXICOS MEDIANTE FOTOGRAFÍA AÉREA E LIDAR EN CASTROS DE GALICIA}

\section{RESUMO}

Varios factores explican que a chamada "arqueoloxía aérea" teña tido moi pouco desenvolvemento en Galicia. Porén, a crecente dispoñibilidade de fontes de información de acceso público (ortofotografías, imaxes de satélite, Lidar) está a mudar este panorama. Neste artigo repasamos eses factores e presentamos múltiples indicios de novos elementos arqueolóxicos que foron identificados na contorna dun amplo conxunto de castros nas provincias de A Coruña e Lugo. Entre os máis de mil elementos identificados hai posibles estruturas soterradas na contorna dos castros (foxos, posibles camiños, restos de parcelas...), trazas de partes dos sistemas defensivos hoxe desaparecidas e mesmo un par de ducias de posibles novos castros. Todos estes achados, que foron feitos de forma inicialmente casual e usando só datos públicos de propósito xeral, xustifican a potencialidade de desenvolver proxectos nesta dirección mediante o uso de plataformas, sensores e planificacións de toma de imaxes especificamente deseñados coa finalidade de documentar elementos arqueolóxicos.

PAlabras ClaVE: Arqueoloxía aérea, Fotografía aérea, Lidar, Castros, Idade do Ferro, Galicia.

\section{EXISTIR, EXISTEN. DETECCIÓN REMOTA DE INDICIOS ARQUEOLÓGICOS MEDIANTE FOTOGRAFÍA AÉREA Y LIDAR EN CASTROS DE GALICIA}

\section{RESUMEN}

Hay varios factores que explican que la llamada "arqueología aérea" haya tenido un desarrollo muy escaso en Galicia. Hoy en día, la creciente disponibilidad de conjuntos de datos de acceso público (ortofotografías, imágenes de satélite, Lidar) está cambiando este panorama. En este artículo repasamos esos factores y presentamos múltiples indicios de nuevos elementos arqueológicos que han sido identificados en el entorno de un amplio conjunto de castros en las provincias de A Coruña y Lugo. Entre los más de mil elementos identificados hay posibles estructuras enterradas en el entorno de esos castros (fosos, posibles caminos, restos de parcelas...), trazas de los sistemas defensivos e incluso un par de docenas de posibles nuevos castros. Todos estos hallazgos, que se produjeron de forma inicialmente casual y usando solo datos públicos de propósito general, justifican la potencialidad de desarrollar proyectos en esta dirección mediante el uso de plataformas, sensores y planificaciones de toma de imágenes específicamente diseñados con la finalidad de documentar elementos arqueológicos.

PALABRAS ClaVE: Arqueología aérea, Fotografía aérea, Lidar, Castros, Edad del Hierro, Galicia.

THEY DO, IN FACT, EXIST. REMOTE DETECTION OF ARCHAEOLOGICAL EVIDENCE OF GALICIAN HILLFORTS USING AERIAL IMAGERY AND LIDAR

\section{ABSTRACT}

Several reasons explain why so-called "aerial archaeology" has rarely been developed in Galicia in the past. Nowadays, the increasing availability of open access datasets (aerial orthoimages, satellite imagery, Lidar data) is beginning to change this outlook. This paper reviews these reasons before presenting various traces of potential archaeological features recently documented around a large group of castros (Iron Age hillforts) in the provinces of A Coruña and Lugo. More than one thousand elements have been identified, including buried features around the sites (ditches, possible pathways, and field boundaries...), traces of levelled defensive elements and even twenty-five previously unknown full sites. These findings are serendipitous in nature and carried out only with the help of public, general-purpose datasets, and they provide a good argument to justify the development of future projects in this direction. The use of bespoke platforms, sensors, and imaging might yield very profitable results in the near future.

KEY WORDS: Aerial archaeology, Aerial photography, Lidar, Hillforts, Iron Age, Galicia. 
Recibido/Received: 03/06/2020

Aceptado/Accepted: 18/10/2020

chamada "arqueoloxía aérea" é unha especialidade cunha longa tradi-
ción en varios lugares, en particular na Europa setentrional, no Medite-
rráneo e no Próximo Oriente. Os antecedentes da identificación de sitios arqueolóxicos dende o aire son case tan antigos como a propia navegación aérea, e non foron senón aumentando en intensidade e regularidade ao longo de todo o século $\mathrm{XX}^{1}$. Nalgúns países mesmo existen programas e institucións dedicadas monográfica e permanentemente á prospección arqueolóxica mediante fotografías aéreas, coma o programa de prospección aérea de Historic England, iniciado en $1967^{2}$ ou o programa equivalente de Historic Environment Scotland ${ }^{3}$, por citar dous dos exemplos con máis tradición. Existen tamén asociacións internacionais, coma o Aerial Archaeology Research Group - $\mathrm{AARG}^{4}$, que son outra boa proba do estendido destas prácticas e da ampla comunidade de expertos existente. $\mathrm{O}$ intenso e rápido desenvolvemento tecnolóxico das últimas décadas deulle un novo pulo á prospección aérea, que hoxe en día forma parte do conxunto máis extenso do que se denomina "remote sensing archaeology", xunto con métodos, técnicas e ferramentas coma a teledetección satelital, o Lidar, os drones...

As contribucións deste tipo de prácticas resultan moitas veces abraiantes, como ilustran algunhas cifras que se poden obter na literatura ou en internet. Así, por exemplo, a web do devandito National Mapping Programme de Historic England anuncia que from 2011 to 2014 over 14000 previously unknown sites were added to the historic environment record from Historic England aerial survey projects 5 . Ou os máis de 200000 "potential archaeological features" (de di-

\footnotetext{
${ }^{1}$ David Raoul WiLson, Air Photo Interpretation for Archaeologists, London, Batsford, 1982; Chris Musson, Rog Palmer e Stefano Campana, Flights Into The Past. Aerial Photography, Photo Interpretation and Mapping for Archaeology, Aerial Archaeology Research, Heidelberg University Library, 2013 (Occasional Publication No. 4).

${ }^{2}$ Historic England [en liña], dispoñible en <https://historicengland.org.uk> [Consulta: 22/04/2020].

${ }^{3}$ Historic Environment Scotland [en liña], dispoñible en <https://www.historicenvironment.scot> [Consulta: 22/04/2020].

${ }^{4}$ Aerial Archaeology Research Group [en liña], dispoñible en <https://a-a-r-g.eu/> [Consulta: 22/04/2020].

5 "Aerial Investigation and Mapping", Historic England [en liña], dispoñible en $<$ https://historicengland. org.uk/research/methods/airborne-remote-sensing/aerial-investigation> [Consulta: 22/04/2020].
} 
versa entidade e certeza) identificados no estado alemán de Baden-Württemberg a través dun programa baseado na interpretación de datos Lidar'6

Porén, noutros lugares como a Península Ibérica en xeral e Galicia en particular, estas prácticas teñen sido moito menos comúns ${ }^{7}$. A principal excepción no noroeste é o uso relativamente común das imaxes do coñecido coma "voo americano" dos anos 1956-1957 para a caracterización de elementos arqueolóxicos de grande escala, coma castros ou explotacións mineiras, dentro dunha paisaxe previa ás grandes transformacións de finais do século $\mathrm{XX}^{8}$.

Á marxe destas aplicacións, o certo é que o recurso á teledetección aérea ten sido escaso aquí. Hai tres factores que axudan a entender ben este feito. $\mathrm{O}$ primeiro ten que ver con que a emerxencia da arqueoloxía aérea viu sempre da man de individuos específicos que combinaban a súa condición de pilotos coa de entusiastas da arqueoloxía (ou, ao revés, arqueólogos/as entusiastas da aviación, coma o caso pioneiro de O.G.S. Crawford). Para facer arqueoloxía aérea é preciso dispoñer de fotografías aéreas. Alén do caso das iniciativas destes individuos singulares, para as rexións máis afectadas por guerras no século XX (Europa central, Oriente Próximo) existiron dende datas temperáns amplos arquivos de imaxes de uso militar que, en moitos casos, foron explotadas con finalidade arqueolóxica ${ }^{9}$. Noutras rexións, ate o recente desenvolvemento de programas públicos de ortofotografía ou de recursos en internet baseados en imaxes de satélite, a única forma de conseguir imaxes aéreas pasaba pola iniciativa propia. Alá onde arqueólogos/as-pilotos non existiron, resultaba moi difícil que se dese o desenvolvemento desta práctica.

\footnotetext{
${ }^{6}$ Ralf Hesse, "The Changing Picture of Archaeological Landscapes: Lidar Prospection over Very Large Areas as Part of a Cultural Heritage Strategy", en Rachel Opitz e Dave Cowley (eds.), Interpreting Archaeological Topography. Airborne Laser Scanning, 3D Data and Ground Observation, Oxford, Oxbow Books, 2013, páxs. 171-183.

7 José Carlos SÁnchez Pardo e Iván Fumadó Ortega, "Aerial Archaeology in Spain: Historiography and Expectations", en Stefano Campana e Maurizio Forte (eds.), From Space to Place. $2^{\text {nd }}$ International Conference on Remote Sensing in Archaeology, Oxford, BAR International Series, 2006, páxs. 65-71; César PARCERo-OubiÑA, "Aerial Archaeology in Spain: Out of the Closet?", AARG News, the Newsletter of the Aerial Archaeology Research Group, 52 (2016), páxs. 12-14.

${ }^{8}$ Francisco Javier Sánchez-Palencia e Almudena Orejas Saco del Valle, "Fotointerpretación Arqueológica: El Estudio Del Territorio", en Assució Vila (ed.), Arqueología, Madrid, CSIC, 1991 (Nuevas Tendencias, 19), páxs. 1-22; Almudena Orejas Saco del Valle, Del Marco Geográfico a la Arqueología del Paisaje. La aportación de la Fotografía Aérea, Madrid, CSIC, 1995 (Monografías, 15); José Manuel Costa-García, "Asentamientos militares romanos en el Norte Peninsular: aportes de la fotografía aérea histórica, la fotografía satelital y el LiDAR aéreo", Férvedes, 8 (2015), páxs. 35-44; Brais CuRRÁs RefoJos, Las sociedades de los castros entre la Edad del Hierro y la dominación de Roma: estudio del paisaje del Baixo Miño, Madrid, CSIC, 2019 (Biblioteca Praehistorica Hispana, 35).

${ }^{9}$ Birger Stichelbaut, Jean Bourgeois, Nick Saunders, e Piet Chielens, Images of Conflict: Military Aerial Photography and Archaeology, Newcastle-upon-Tyne, Cambridge Scholars Publishing, 2009; David Cowley, Lesley Ferguson e Allan Williams, "The Aerial Reconnaissance Archives: A Global Aerial Photographic Collection", en William Hanson e Ioana Oltean (eds.), Archaeology from Historical Aerial and Satellite Archives, New York, Springer, 2013, páxs. 13-30.
} 
Un segundo factor importante no caso de Galicia é a particular morfoloxía da súa paisaxe. Segundo os datos tirados da cartografía de CORINE Land Cover de 2018, a superficie cultivada ocupa aquí aproximadamente só un 30\% do territorio, mentres que as superficies arboradas esténdense por case o $38 \%$ e, sumadas ao monte baixo, abranguen algo máis do $66 \%{ }^{10}$. Estas non son as mellores condicións para a detección de elementos a través das fotografías aéreas: a ampla maioría dos indicios que se identifican nelas fano en forma ben de cropmarks (marcas visibles como crecemento diferencial dos cultivos, esencialmente de cereais), ben de soilmarks (marcas visibles a través da diferente tonalidade do solo, usualmente indicativas de zonas con máis profundidade). Á escasa porcentaxe de terreos cultivados hai que engadir o feito de que moitos deles están dedicados a especies que non son especialmente propicias para identificar indicios coma os descritos (millo, patacas, vides, cultivos de horta...). Estas condicións fan que, a priori, o potencial da detección aérea aquí sexa bastante baixo.

Pero hai aínda un terceiro factor importante: a superficie media das parcelas catastrais rústicas en Galicia é de $0,25 \mathrm{ha}^{11}$. Esta ben coñecida fragmentación do parcelario é aínda un factor máis que dificulta a identificación de indicios en imaxes aéreas, xa que impide a posibilidade de visualizar zonas continuas extensas nunhas mesmas condicións e, xa que logo, de converter pequenos cambios no terreo en indicios consistentes pola súa extensión.

Non é estrano, pois, que a detección remota baseada en imaxes aéreas teña sido tan pouco empregada en Galicia. Estes factores pasaron a ser todos eles relativamente pouco importantes coa aparición do Lidar, unha tecnoloxía baseada non en principios ópticos senón no emprego de pulsos láser. Dende a súa aparición, e grazas á pública dispoñibilidade de datos de todo o territorio, o Lidar está a posibilitar un importante pulo na identificación de novos sitios arqueolóxicos ou na mellora da documentación dos xa coñecidos ${ }^{12}{ }^{13}$. A análise dos datos Lidar permite identificar elementos xa non en forma de anomalías de cor ou textura, senón de diferenzas topográficas, mediante o que se coñece coma shadowmarks.

Malia todo o dito, o traballo que aquí presentamos amosa como as series de imaxes aéreas de cobertura xeral dispoñibles hoxe en día de forma pública

\footnotetext{
${ }^{10}$ Elaboración propia a partir dos datos de Corine dispoñibles en CENTRO NACIONAL DE INFORMACIÓN GEOGRÁFICA [en liña], <http://centrodedescargas.cnig.es/> [Consulta: 22/04/2020].

${ }^{11}$ Cálculo propio a partir da ferramenta de estatísticas do Catastro: DireCción General De CaTAstro [en liña], dispoñible en <http://www.catastro.minhap.gob.es/esp/estadisticas.asp> [Consulta: 22/04/2020].

12 José Manuel Costa-García, João Fonte e Manuel Gago, "The Reassessment of the Roman Military Presence in Galicia and Northern Portugal through Digital Tools: Archaeological Diversity and Historical Problems", Mediterranean Archaeology and Archaeometry, 19 (2019), páxs. 17-49.

${ }^{13}$ Nunha liña similar, neste verán de 2020 anunciouse na prensa a descoberta, mediante unha combinación de fotointerpretación e Lidar, dun complexo militar de época romana en San Andrés de Rabanedo (León), por parte de A. Morillo, A. Orejas, B. Currás e A. Nobilini, aínda pendente de publicación.
} 
a través de diferentes lugares, combinadas co detalle dos datos Lidar (segundo logo indicamos), si teñen un certo potencial para a identificación de indicios de elementos arqueolóxicos de forma remota na paisaxe galega. O que aquí presentamos é un bo exemplo de serendipia: algo achado mentres realmente se estaba a procurar outra cousa. Todo xurdiu no marco dunha investigación orientada a comparar a extensión e complexidade arquitectónica dun amplo conxunto de castros dentro dunha área duns $8000 \mathrm{~km}^{2}$ entre as provincias de A Coruña e Lugo (figura 1). Unha parte esencial deste traballo pasaba por delimitar con detalle a extensión de cada castro e dos seus sistemas defensi$\operatorname{vos}^{14}$. Para iso, recorremos inicialmente ao emprego dos datos Lidar que fomos logo complementando co exame das fotografías aéreas dispoñibles. Foi o uso combinado destas dúas fontes o que nos permitiu comezar a identificar indicios diversos na contorna de varios castros, e aos poucos fomos centrando a nosa atención neses elementos ate completar unha colección bastante ampla e, parécenos, significativa, que suxire que o potencial dos datos dispoñibles é relativamente grande.

A continuación detállase a metodoloxía e fontes de datos que foron usadas, antes de presentar os resultados obtidos, usando algúns exemplos seleccionados para ilustrar a variedade de indicios identificados.

\section{MetodoloxíA E FONTES}

A metodoloxía seguida foi bastante sinxela e baseouse no uso sistemático de recursos dispoñibles online, ben mediante conexión directa ou ben mediante descarga e procesado. Todo o que se describe de seguido fíxose usando ArcGIS desktop 10.5, aínda que os procedementos manexados (conexión a servidores OGC, edición vectorial) son totalmente estándar e podería terse empregado indistintamente calquera outro software SIX (agás para o procesado dos datos Lidar, como de seguido se detalla).

Por unha banda, creouse, para a zona de traballo (figura 1) ${ }^{15}$, unha visualización de mapa de sombras do modelo dixital do terreo de $1 \mathrm{~m}$ de resolución producido a partir de datos Lidar e dispoñible publicamente no sitio web mapas. xunta.gal. Sobre ese mapa colocouse a capa vectorial de sitios inventariados no Inventario Arqueolóxico de Galicia, dispoñible tamén para descarga no visor do

\footnotetext{
${ }^{14}$ César PARCERo-OubiÑa e Samuel Nión, "Forms of Settlement Inequality across the Space. A GISBased Method for Measuring Settlement Differences”, Journal of Archaeological Science:Reports 35 (2021), 102739.

${ }^{15}$ Unha versión en cores das figuras deste artigo está dispoñible en DigiTAL CSIC [en liña], <http://hdl. handle.net/10261/210565> [Consulta: 22/04/2020].
} 


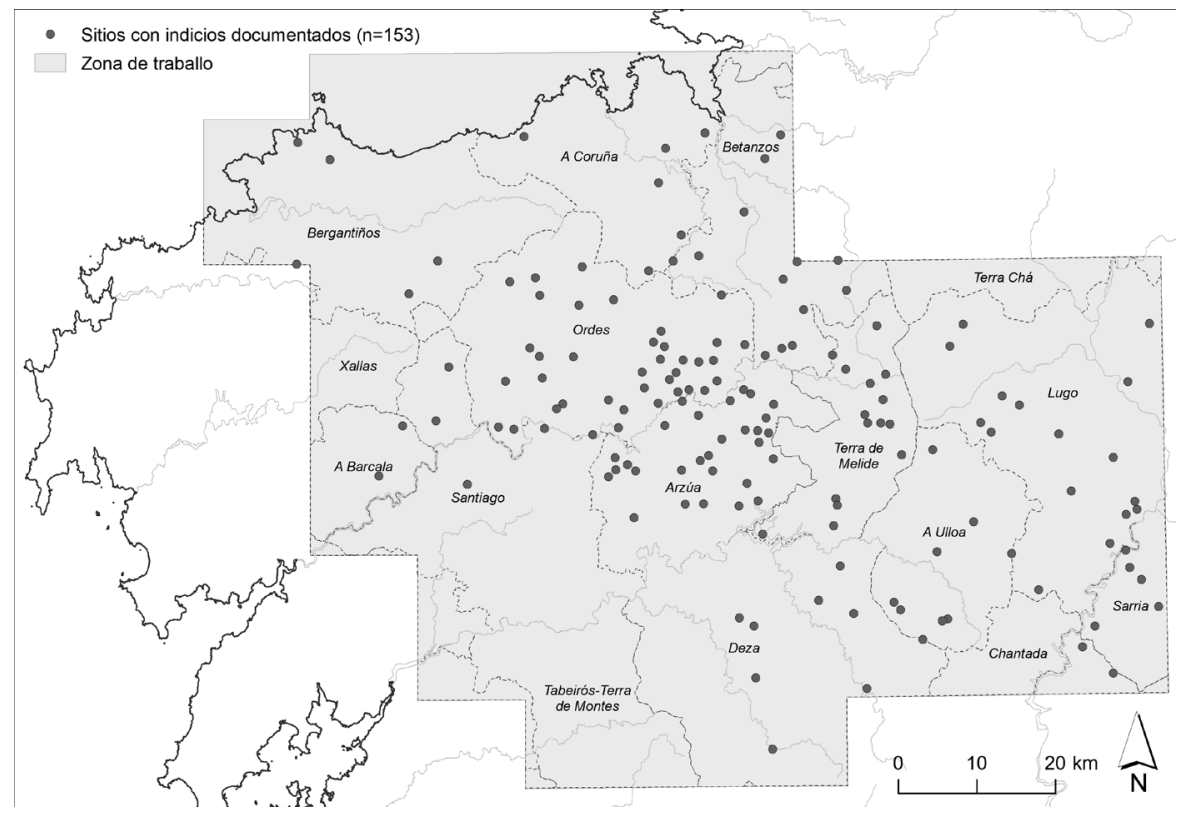

Figura 1. Zona de traballo e localización dos sitios nos que se documentaron indicios. Amósanse as comarcas incluídas na zona de traballo.

Plan Básico Autonómico ${ }^{16}$. Usando esas dúas capas como base, foise revisando a totalidade da zona de traballo (con diferente intensidade, como de seguido explicamos), deténdonos en cada castro para delimitalo coa maior precisión posible. Para a delimitación dos casos máis sinxelos seguimos os indicios visibles no mapa de sombras e, en caso de dúbidas, recorremos á consulta das ortoimaxes históricas publicadas, mediante servicio WMS, polo Instituto Geográfico Nacional ${ }^{17}$, a saber:

- Voo americano, serie B, dos anos 1956-1957

- SIGPAC, feita entre 1997-2003

- PNOA, dos anos 2005, 2008, 2009, 2010, 2011, 2014 e 2017

Adicionalmente, nos casos máis sobranceiros, recorremos tamén á consulta das imaxes de satélite históricas dispoñibles no visor Google Earth.

\footnotetext{
${ }^{16}$ Xunta de Galicia, Información Xeográfica de Galicia [en liña], dispoñible en < http://mapas.xunta. gal/visores/pba/> [Consulta: 22/04/2020].

${ }^{17}$ Instituto GeOgRÁfiCo NACIONAL [en liña], dispoñible en <http://www.ign.es/wms/pnoa-historico> [Consulta: 22/04/2020].
} 
Finalmente, naqueles casos nos que se considerou necesario, producíronse visualizacións complementarias dos datos Lidar, orientadas a obter un resalte máis evidente das anomalías topográficas ${ }^{18}$. Todas estas visualizacións foron creadas coa ferramenta Relief Visualization Toolbox ${ }^{19} 20$. O que resultou ser máis útil na meirande parte dos casos foi a combinación do Local Relief Model ${ }^{21}$ co mapa de sombras.

A combinación de todas estas fontes permitiunos delimitar con suficiente detalle a meirande parte dos castros coñecidos na zona para os fins propostos, pero tamén permitiunos ir descubrindo unha serie de indicios de variada natureza que proporcionan nova información sorprendente acerca de moitos destes castros (figura 1), e incluso aportan un número non menor de novos castros previamente non inventariados, como se explica máis adiante. Todos estes novos indicios foron rexistrados nunha capa vectorial de liñas, cuxa táboa de atributos contén información detallada acerca da fonte ou fontes cartográficas nas que ese indicio foi observado ${ }^{22}$. A comprobación da novidade dos elementos identificados fíxose verificando a súa presencia ou ausencia en dúas fontes esenciais:

- A devandita capa de sitios inventariados no Inventario Arqueolóxico de Galicia, segundo está dispoñible no visor do Plan Básico Autonómico ${ }^{23}$.

- Os datos incluídos nos catálogos e cartografías dos correspondentes planeamentos urbanísticos municipais, no caso dos concellos que dispoñen deles ${ }^{24}$.

Isto que chamamos de forma xenérica indicios pode consistir en dous tipos de evidencias. Por unha banda, anomalías topográficas visibles a través dos datos Lidar, usualmente en forma de elevacións ou depresións no terreo, para as que atopamos ben práctico empregar o termo inglés habitual de shadowmarks xa que, en efecto, visualízanse grazas á proxección de luces e sombras sobre a información topográfica. Por outra banda, atopamos unha grande cantidade de trazos visibles nas imaxes aéreas ou de satélite en forma de marcas de cor ou tonalidade contrastante co terreo circundante. Para elas empregamos o termo ta-

\footnotetext{
18 Žiga KoKalj e Ralf Hesse, Airborne Laser Scanning Raster Data Visualization. A Guide to Good Practice, Ljubljana, Založba ZRC, 2017.

19 Žiga KoKalj e Maja SomraK, "Why Not a Single Image? Combining Visualizations to Facilitate Fieldwork and On-Screen Mapping”, Remote Sensing, 11, 7 (2019), páxs. 1-26.

${ }^{20}$ Dispoñible en Slovenian ACADEMY OF ARTS AND SCIENCES, $<$ https://iaps.zrc-sazu.si/en/rvt\#v> [Consulta: 22/04/2020].

${ }^{21}$ Ralf Hesse, "LiDAR-Derived Local Relief Models - a New Tool for Archaeological Prospection", Archaeological Prospection, 17, 2 (2010), páxs. 67-72.

${ }^{22}$ Capa completa dispoñible en DigITAL CSIC [en liña], <http://hdl.handle.net/10261/210565>

${ }^{23}$ Xunta de Galicia, Información Xeográfica de Galicia [en liña], dispoñible en < http://mapas.xunta. gal/visores/pba/> [Consulta: 22/04/2020].

${ }^{24}$ Dispoñibles en XunTA DE GALICIA [en liña], < http://www.planeamentourbanistico.xunta.es/siotuga/> [Consulta: 22/04/2020].
} 
mén habitual de soilmarks, xa que estes indicios correspóndense de forma xeral coa tradución na superficie do terreo de diferenzas na humidade que, á súa vez, indican diferenzas na profundidade do solo.

\section{Resultados: TIPOS E EXEMPlos DE EVIDENCIAS DOCUMENTADAS}

A presentación da evidencia recoñecida pode comezar aportando algúns datos cuantitativos: mediante o proceso descrito nos apartados anteriores, fomos quen de identificar un total de 1397 indicios de posibles elementos arqueolóxicos en ou na contorna de $153 \operatorname{sitios}^{25}$. Como xa foi dito, case todos estes sitios seguen os patróns morfolóxicos característicos dos castros. Cumpre dicir que esa cifra de 1397 indicios correspóndese á suma de cada unha das marcas individuais identificadas nas distintas fontes de datos xeoespaciais analizadas. Isto quer dicir que, por exemplo e como se ilustra na figura 2, cada segmento dunha aparentemente mesma estrutura que se identificou nun conxunto de fontes diferentes foi recollido como una evidencia individual distinta.

Os indicios identificados poden presentarse agrupados en catro clases, en función do grao de novidade que supoñen respecto ao coñecemento previo existente respecto aos sitios en cuestión:

1. Partes de sitios total ou parcialmente destruídos. Nestes casos, a súa existencia era coñecida pero pouco ou nada se sabía daquelas partes destruídas (en ocasións a totalidade do sitio).

2. Elementos novos identificados na contorna de sitios xa coñecidos e ben preservados. Nestes casos, o aporte consiste sobre todo en redimensionar a morfoloxía, escala e extensión dos sitios mediante a incorporación de indicios de elementos novos non visibles sobre o terreo.

3. Identificación de sitios novos, non coñecidos previamente.

4. Localización de elementos indeterminados de potencial interese arqueolóxico. Nestes poucos casos trátase de anomalías que non se corresponden con claridade con elementos recoñecibles pero que poderían ter unha orixe antiga indeterminada.

A continuación preséntanse algúns exemplos ilustrativos de cada unha destas categorías de elementos identificados. Por razóns de extensión, escollemos unicamente uns poucos casos como mostra. Os casos escollidos son aqueles que se consideraron máis representativos da variedade de elementos documentados. As persoas interesadas en revisar os resultados con máis detalle poden descargarse

${ }^{25}$ Cifras contabilizadas a data 15 de abril de 2020. 


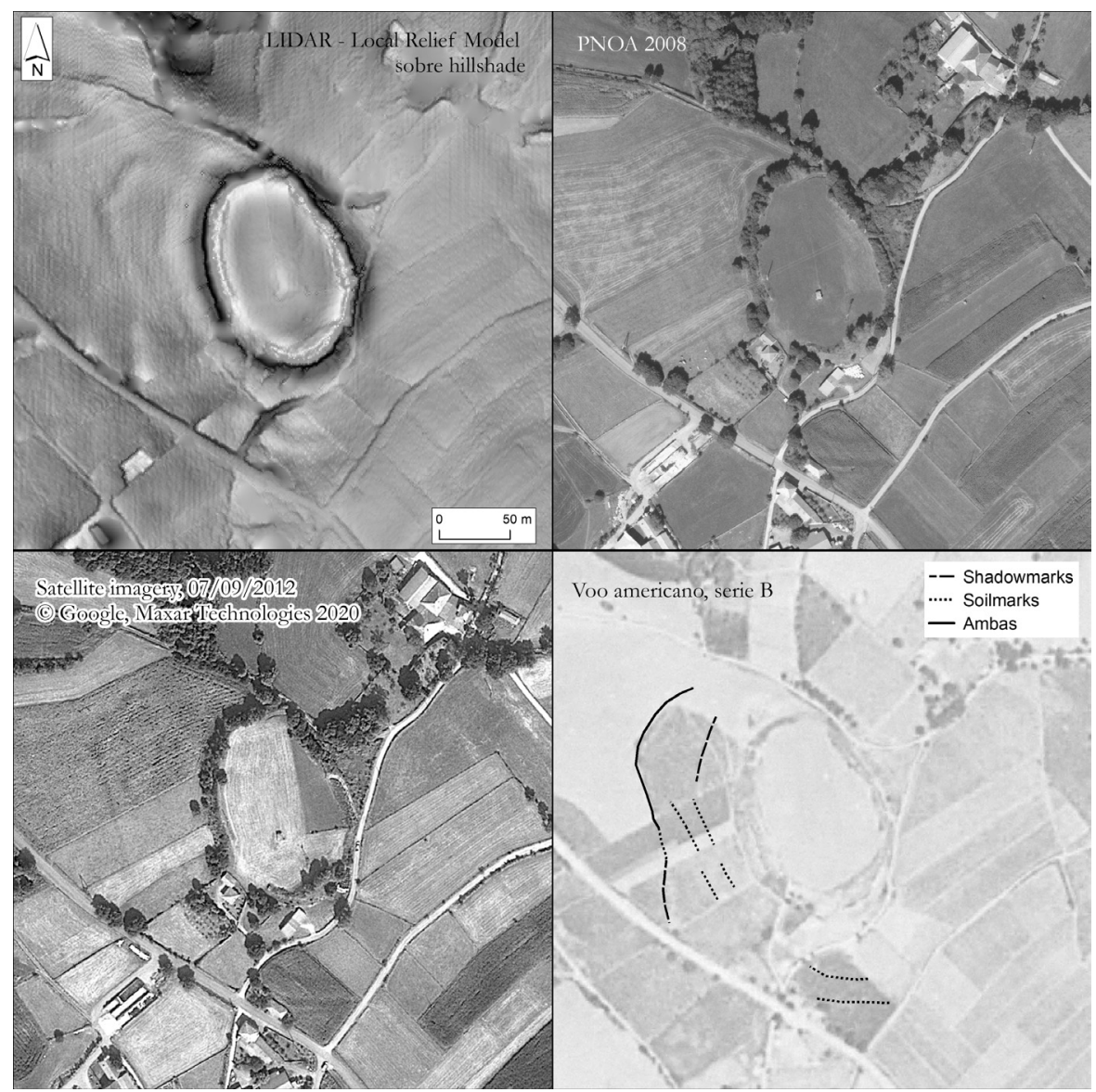

Figura 2. Malia que é razoable consideralos parte dunhas mesmas estruturas soterradas (probablemente foxos), as liñas visibles na figura foron rexistradas coma indicios diferentes porque son visibles en fontes diferentes (castro de Orxainza, O Saviñao).

unha capa vectorial (shapefile) coa totalidade dos elementos identificados ate a data, incluíndo a mención da fonte ou fontes nas que foron identificados ${ }^{26}$.

\section{DOCUMENTACIÓN DE SITIOS TOTAL OU PARCIALMENTE DESTRUÍDOS}

Trátase, coma foi dito, de sitios xa recoñecidos como tales no Inventario Arqueolóxico de Galicia e/ou nas outras fontes consultadas (ver Metodoloxía e

\footnotetext{
${ }^{26}$ Dispoñible en Digital CSIC [en liña], <http://hdl.handle.net/10261/210565> [Consulta: 27/11/2020].
} 
fontes), pero que están total ou parcialmente destruídos e dos que non se conservan elementos visibles na superficie en todo ou en parte da súa extensión. $\mathrm{O}$ aporte achegado neste caso consiste no recoñecemento de restos de eses sectores desmantelados e, polo tanto, na posibilidade de recrear total ou parcialmente a morfoloxía orixinal dos sitios. Por extensión, isto pode contribuír a mellorar as figuras de protección patrimonial destes espazos.

Un bo exemplo de sitio parcialmente desmantelado é o Castro das Medorras (Sta. María de Buazo, Boimorto) que, coma outros moitos casos, foi parcialmente arrasado pola concentración parcelaria pero consérvase moi ben visible no voo americano (figura 3). Porén, no sector afectado pola concentración aínda son perceptibles con claridade evidencias da traza orixinal, tanto a través de

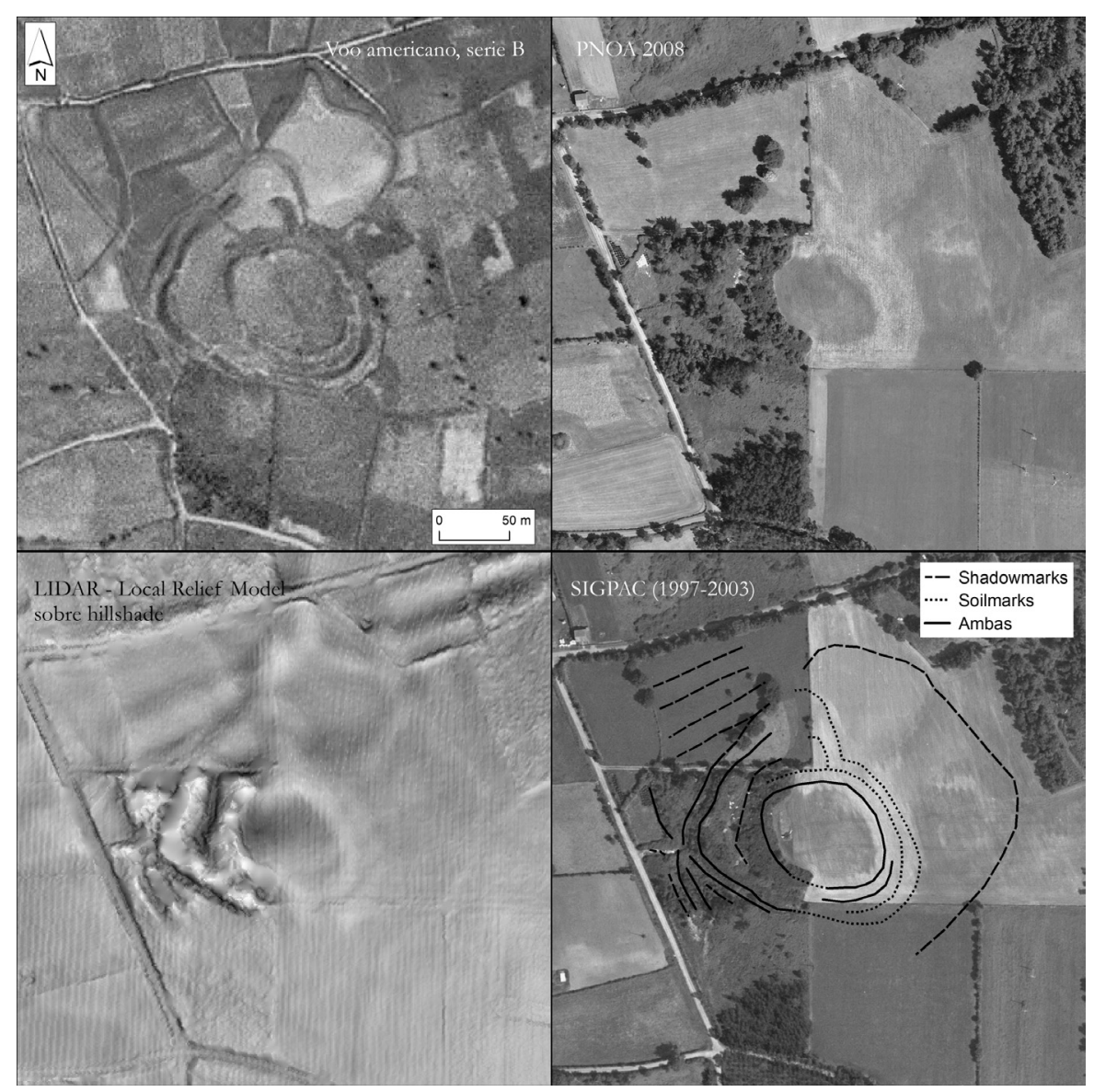

Figura 3. Indicios documentados no Castro das Medorras (Sta. María de Buazo, Boimorto). 
soilmarks coma en forma de diferenzas topográficas nos datos Lidar. De feito algunhas das marcas visibles aportarían novas estruturas na contorna alén do visible no voo americano.

Resultan se cadra máis novidosos outros casos nos que o voo americano non aporta moita información, pero si a manipulación dos datos Lidar combinados con algunhas imaxes aéreas máis recentes. Un exemplo é o sitio de A Medorra do Gavión (Sta. Mariña de Parada, Ordes). Na superficie hoxe en día semella que non hai moitas evidencias visibles pero unha inspección dalgunhas imaxes aéreas e satelitais e máis unha visualización máis contrastada da topografía Lidar permite identificar unha boa cantidade de posibles elementos, moitos dos cales non teñen correspondencia co parcelario actual nin co visible no voo americano (figura 4).

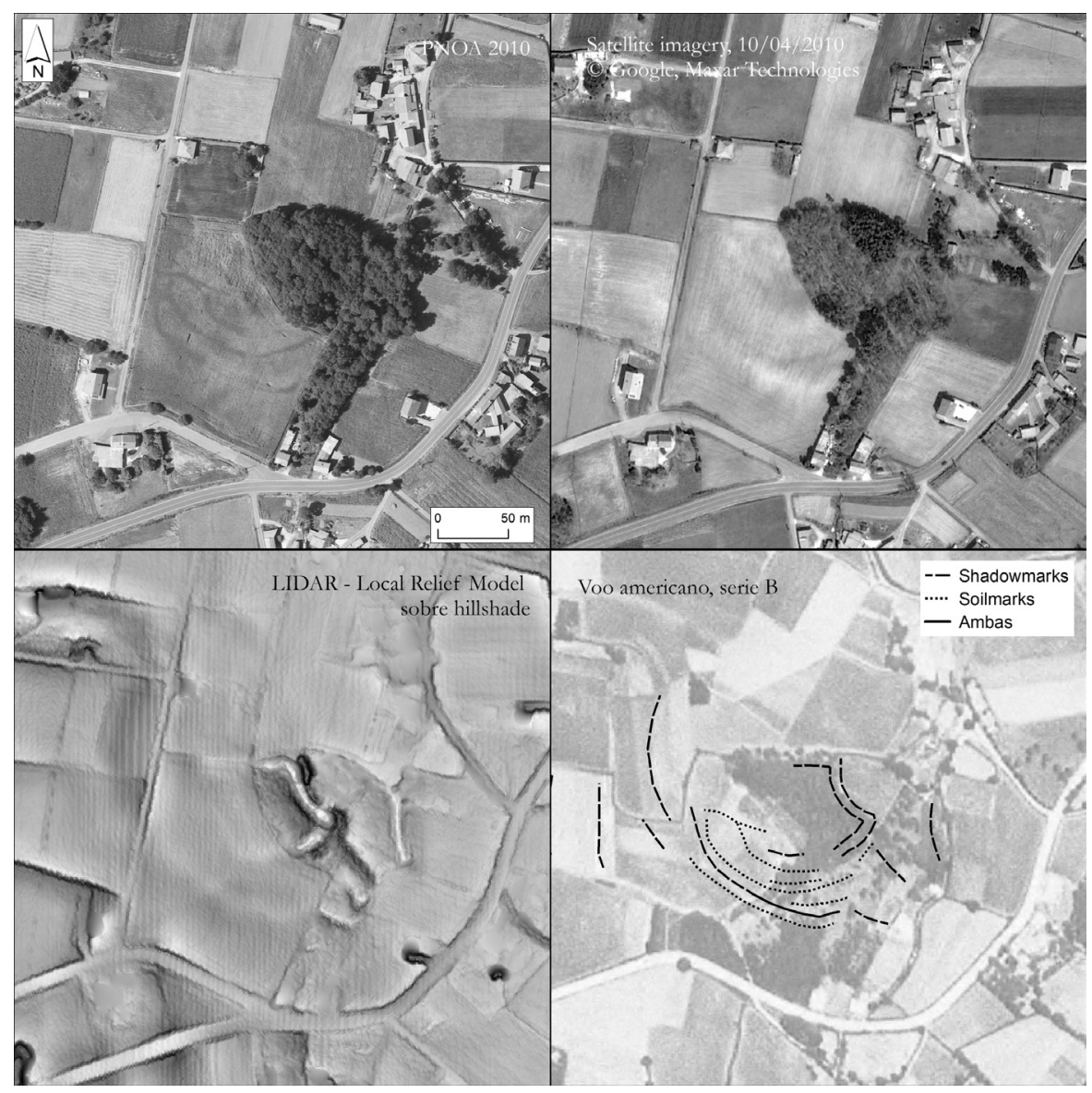

Figura 4. Indicios documentados en A Medorra do Gavión (Sta. Mariña de Parada, Ordes). 


\section{IDENTIFICACIÓN DE ELEMENTOS NOVOS ARREDOR DE SITIOS COÑECIDOS}

A meirande parte dos elementos identificados entran dentro desta categoría. En moitos casos os indicios son apenas unhas poucas soilmarks ou shadowmarks, indicativas frecuentemente de posibles foxos (figura 2) pero tamén doutro tipo de elementos non determinados (camiños, parcelarios...). Porén, escolléronse aquí algúns casos onde a variedade e densidade de indicios é maior. Por riba, en todos eles dáse unha reiteración na identificación dos indicios en varias imaxes, o que redunda no nivel de certeza sobre a súa importancia.

Un primeiro exemplo é o Coto das Medorras (San Pedro de Aiazo, Frades). Trátase dun castro cuxas estruturas delimitadoras semellan case completamente

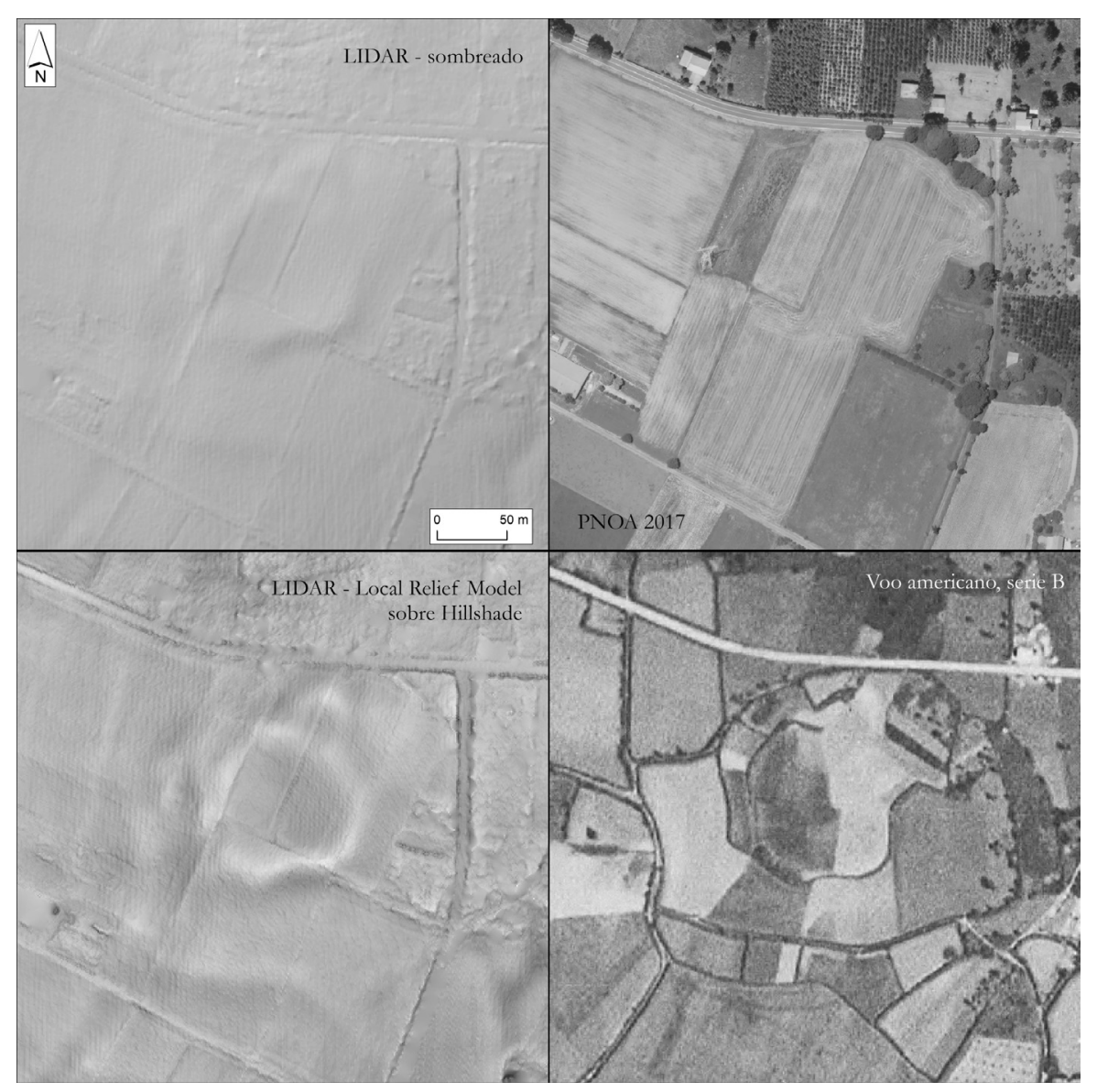

Figura 5. Coto das Medorras (San Pedro de Aiazo, Frades). 
arrasadas en boa parte do seu perímetro, especialmente no SE; así se describe na correspondente ficha do planeamento municipal, do ano 2018. Efectivamente, o mapa de sombreado do Lidar permite adiviñar con certa claridade a contorna orixinal desas defensas, que aínda se conservaban como límites de parcelas na época do voo americano pero que xa se ven perdidas na ortoimaxe do ano 2017 (figura 5). Porén, unha visualización diferente da topografía documentada co Lidar permite empezar a intuír con máis claridade a morfoloxía orixinal do sitio.

A sorpresa neste caso chega coa ampla cantidade e variedade de elementos que se identifican nalgunhas imaxes aéreas e de satélite de entre os anos 2009 e 2017 (figura 6). Non só son perfectamente visibles os límites orixinais da muralla central e foxos do castro, senón tamén outros moitos indicios entre os que

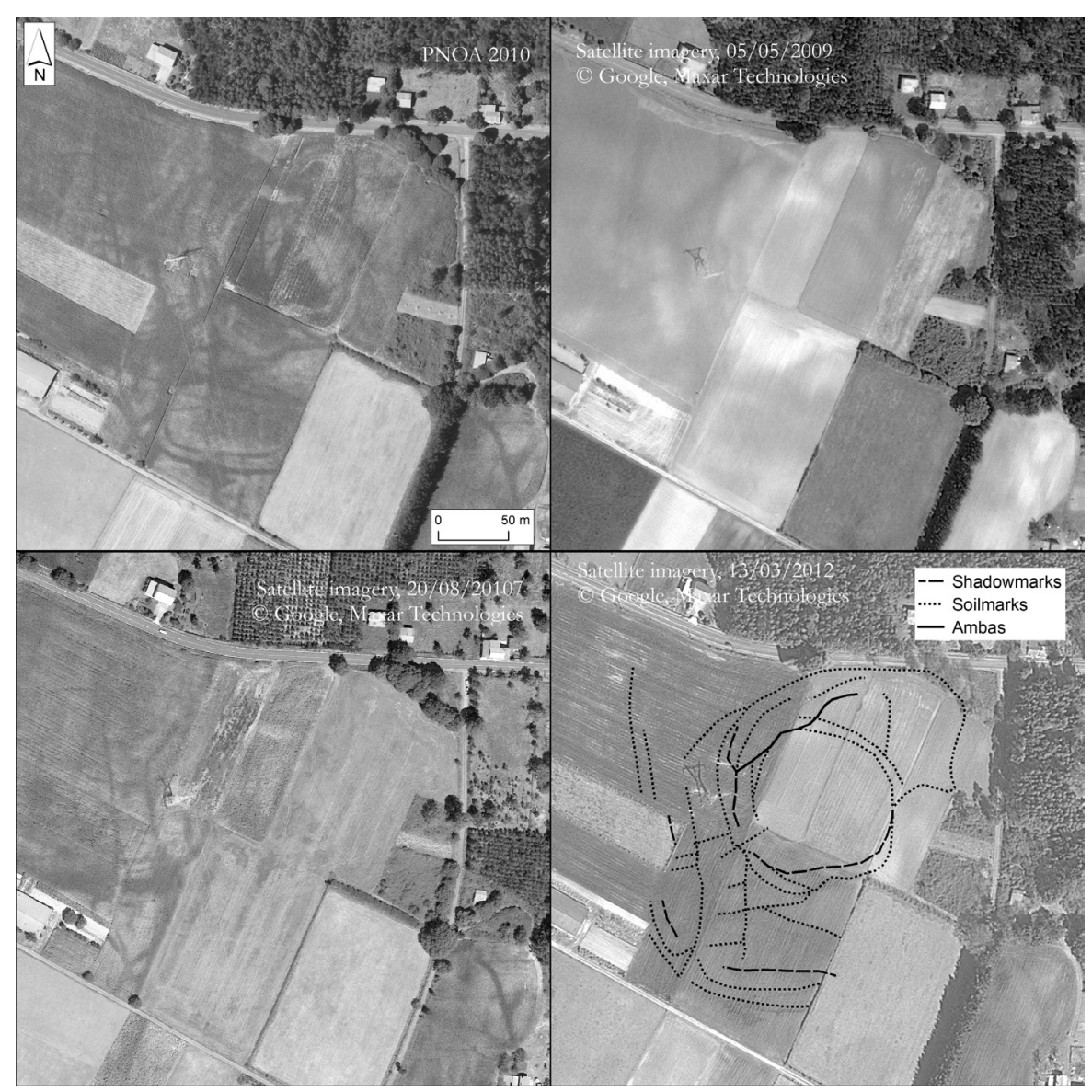

Figura 6. Coto das Medorras (San Pedro de Aiazo, Frades): elementos identificados na contorna. 
destaca o que podería ser un sistema de acceso que atravesa un conxunto de dous novos foxos localizados a uns 70 metros ao Sur do recinto central. Amais diso, outro amplo conxunto de liñas que poderían indicar novos foxos, camiños ou incluso restos dun sistema parcelario.

Dúas cousas resultan especialmente senlleiras neste caso. A primeira é a notable cantidade de elementos visibles, moitos deles ademais consistentes a través de varias imaxes, que permiten ampliar notablemente a extensión orixinalmente suposta do sitio. A segunda, máis ben metodolóxica, é a interesante diferenza entre dúas imaxes tomadas no mesmo ano 2017 (figura 5 e figura 6): nunha delas, na que os campos semellan estar recentemente colleitados, non se observa nada



Figura 7. Evidencias documentadas na contorna de O Castro de Mosteiro (Sta. María de Mosteiro, Guntín). 




Figura 8. Elementos documentados na contorna de A Medorra do Cura/Castro de Oirós (Sta. María de Oirós, Vila de Cruces).

destacable, pero na outra, tomada a finais do verán, hai moitos elementos ben visibles. Isto é un exemplo práctico ben ilustrativo da importancia dos momentos de observación ao longo do ano (tamén chama a atención que noutra imaxe onde os campos están arados, a finais da primavera de 2009, si se aprecian moitas marcas no terreo). Desafortunadamente, non temos as datas concretas das imaxes do PNOA, pero semella que a de 2010 tamén foi tomada nalgún momento do verán, en contraste coa de 2017.

Outro bo exemplo da documentación dun conxunto amplo de evidencias na contorna dun sitio coñecido é o Castro de Mosteiro (Sta. María de Mosteiro, Guntín) (figura 7). Neste caso o sitio está, de novo, bastante mal conservado, 
e nin a topografía do Lidar nin a foto do voo americano proporcionan moita información relevante. Porén, as imaxes do PNOA de 2011 e 2017 permiten ver un conxunto relativamente denso de indicios que poderían corresponderse con elementos de distinto tipo: camiños, límites de parcelas e incluso un posible foxo exterior que indicaría a posible existencia dun segundo recinto ao SE do suposto recinto central do sitio. Un elemento rechamante aquí é a distancia respecto ao sitio na que se atopan algúns destes indicios.

O derradeiro exemplo que se presenta, de entre os moitos casos documentados deste tipo, é o de A Medorra do Cura (Sta. María de Oirós, Vila de Cruces) (figura 8). Este caso escolleuse non pola cantidade ou espectacularidade dos indicios atopados, senón pola representatividade que teñen doutros moitos dos casos descubertos: un castro aparentemente sinxelo e pequeno, formado por un único recinto que, porén, podería ter tido un sistema de estruturas defensivas composto a lo menos por 3 ou ate 4 foxos e parapetos na cara Oeste. Tal cantidade de foxos adicionais non é frecuente, pero moitos outros dos casos documentados aportaron posibles foxos exteriores como elementos máis destacados (por exemplo o caso da figura 2).

\section{DETECCIÓN DE NOVOS SITIOS}

A identificación de posibles novos sitios, previamente non inventariados nas fontes consultadas, constitúe se cadra o aporte máis rechamante. Como xa foi dito, inicialmente contrastamos tódolos sitios localizados coas versións publicamente accesibles do Inventario Arqueolóxico de Galicia e máis dos planeamentos urbanísticos municipais. En relación con esas fontes, tiñamos un total de 47 sitios novos. Porén, dado que estas fontes están en constante actualización e as versións públicas poden estar incompletas, quixemos verificar estes sitios directamente con técnicos da Dirección Xeral de Patrimonio ${ }^{27}$. O resultado foi que o número de sitios non inventariados é de 25 (o resto si eran xa coñecidos pero aínda non figuran na versión pública do xeoportal do Plan Básico Autonómico). Malia que é necesario verificar no terreo os indicios aquí localizados, e que algúns destes 25 sitios son máis dubidosos ca outros, a cifra non deixa de ser rechamante para un tipo de elementos, os castros, tan idiosincráticos e recoñecibles na paisaxe, na toponimia e na tradición oral. Amósanse de seguido algúns dos exemplos máis interesantes.

A meirande parte dos sitios deste grupo foron identificados unicamente a través da visualización dos datos Lidar, pero nalgúns casos tamén se aprecian indicios nas imaxes aéreas. Se cadra o exemplo máis rechamante é o Castro de Fonte Outeiro (Sta. María de Dodro, Arzúa) (figura 9). En principio, a imaxe da

\footnotetext{
${ }^{27}$ Agradezo moito a Ignacio Vilaseco a súa dispoñibilidade para revisar a lista de sitios que lle enviei e a súa rapidez e eficacia en comprobar o estado de todos eles no inventario.
} 
topografía sombreada do Lidar apenas permite intuír a posible existencia dos restos dun recinto oval (na esquina superior dereita das imaxes), que tamén se aprecia no voo americano, malia que xa non ten hoxe en día correspondencia con ningún límite de parcelas. Porén, unha visualización alternativa dos mesmos datos Lidar posibilita empezar a identificar, alén do recinto oval (que resulta ben evidente), unha ampla serie de anomalías topográficas, moitas delas restos do parcelario visible no voo americano.

Coa axuda dalgunhas imaxes aéreas e de satélite podemos ver como hai efectivamente unha longa serie de marcas na contorna (figura 10), non moi distintas das que xa vimos nalgúns exemplos do apartado anterior. A imaxe do PNOA de 2010 volta ser unha das fontes máis útiles para identificar distintas liñas que

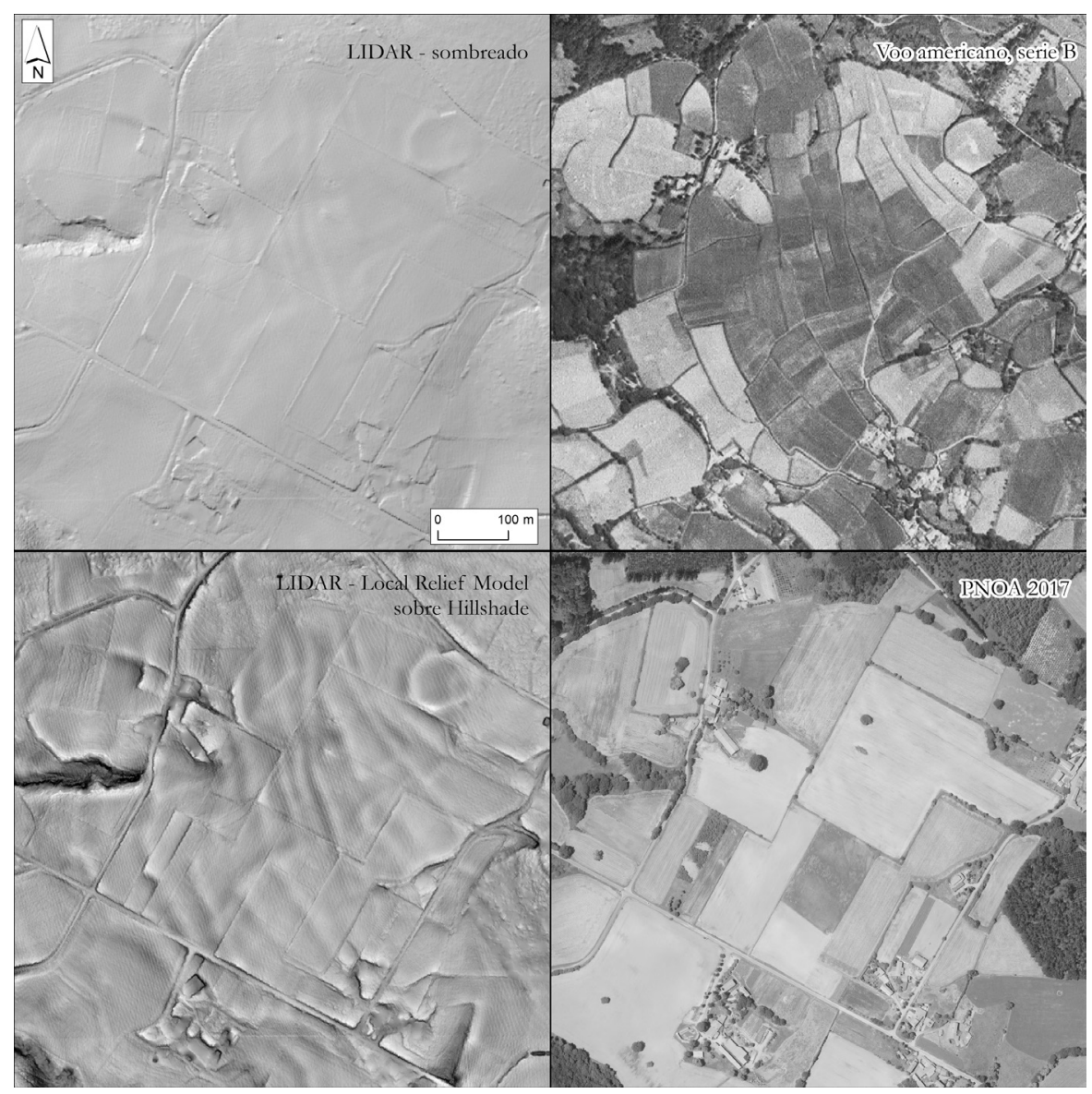

Figura 9. Castro de Fonte Outeiro (Sta. María de Dodro, Arzúa): primeiros indicios dun posible castro moi arrasado. 




Figura 10. Castro de Fonte Outeiro (Sta. María de Dodro, Arzúa): máis indicios dun posible castro moi arrasado e dunha boa cantidade de elementos na súa contorna.

podería corresponderse con foxos, gabias, camiños, parcelas... Cumpre insistir en que na interpretación visible na figura 10 xa foron descartados aqueles trazos que corresponden a parcelas observables no voo americano.

Menos espectacular pero se cadra moito máis claro é o caso do castro identificado en Revolta do Pingo (Sta. María de Viladavil, Arzúa / Sta. María de Sendelle, Boimorto) (figura 11). Aquí, a extensión das evidencias é limitada, pero tanto na topografía do Lidar coma nalgunhas imaxes aéreas apréciase con moita claridade un recinto oval delimitado por unha muralla - foxo - antefoxo ben conservados ao Norte e arrasados, pero con indicios claros, ao Sur. Adicionalmente, hai algunhas outras marcas topográficas que suxiren un posible sistema de acceso no Surleste. 


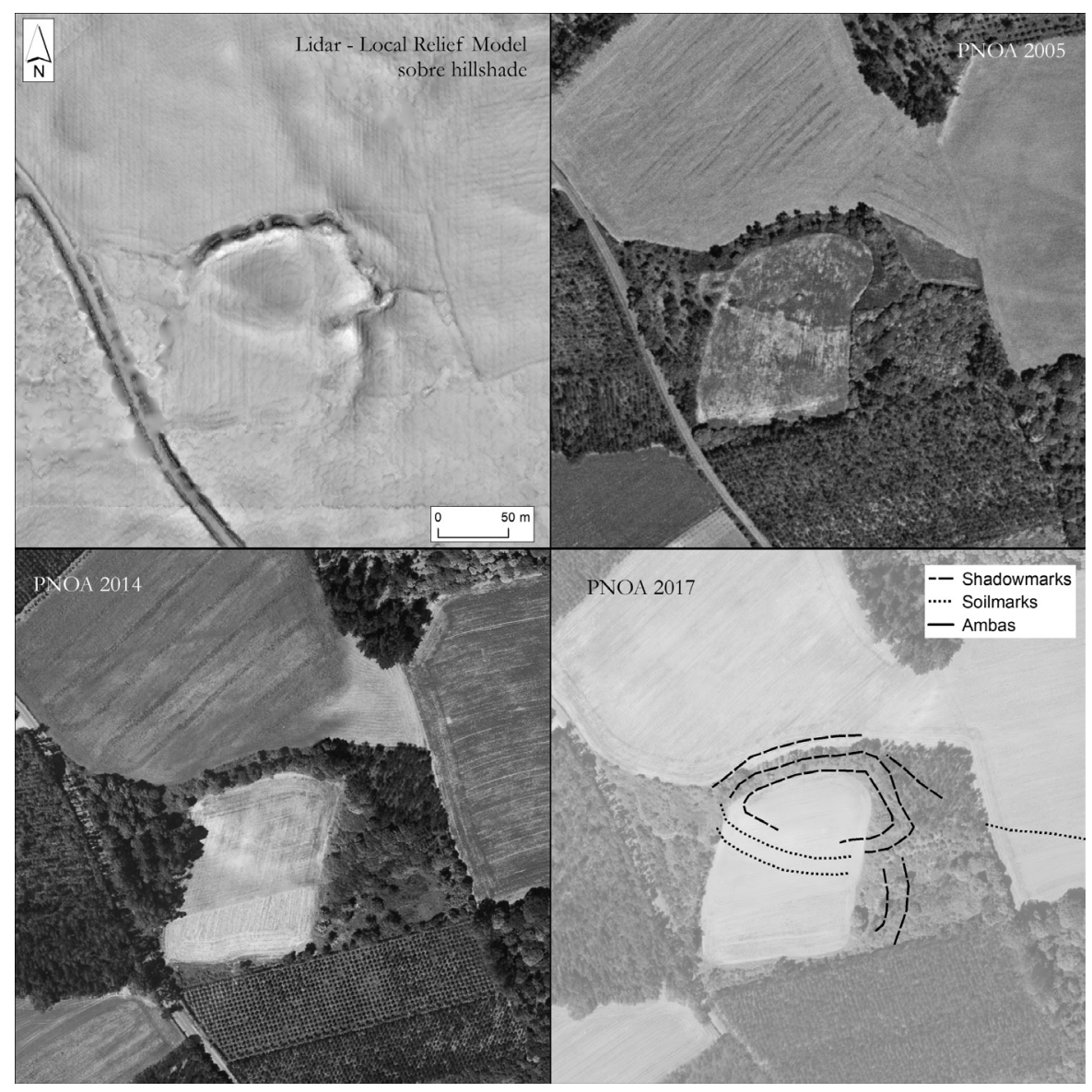

Figura 11. Castro non coñecido en Revolta do Pingo (Sta. María de Viladavil, Arzúa / Sta. María de Sendelle, Boimorto).

Como foi dito, a meirande parte destes novos sitios foron identificados unicamente a través de visualizacións dos datos Lidar. A figura 12 amosa un dos mellores exemplos, o castro localizado en Bullas de Arriba, Vilasantar. Localizado nunha zona densamente arborada, ningunha das fotografías aéreas resulta de moita axuda, pero a imaxe sombreada do Lidar xa permite intuír un conxunto que resulta moito máis evidente cando eses mesmos datos se visualizan doutra forma. O topónimo castro do sitio é unha confirmación adicional que tamén se da noutros moitos casos dos que foron identificados deste xeito.

O derradeiro exemplo deste bloque é un posible sitio que, máis que un castro, semella un recinto dalgún outro estilo. Localízase en Vilaboil (Sta. María de Castrofeito, O Pino) (figura 13). A combinación do Lidar e algunhas imaxes aéreas 


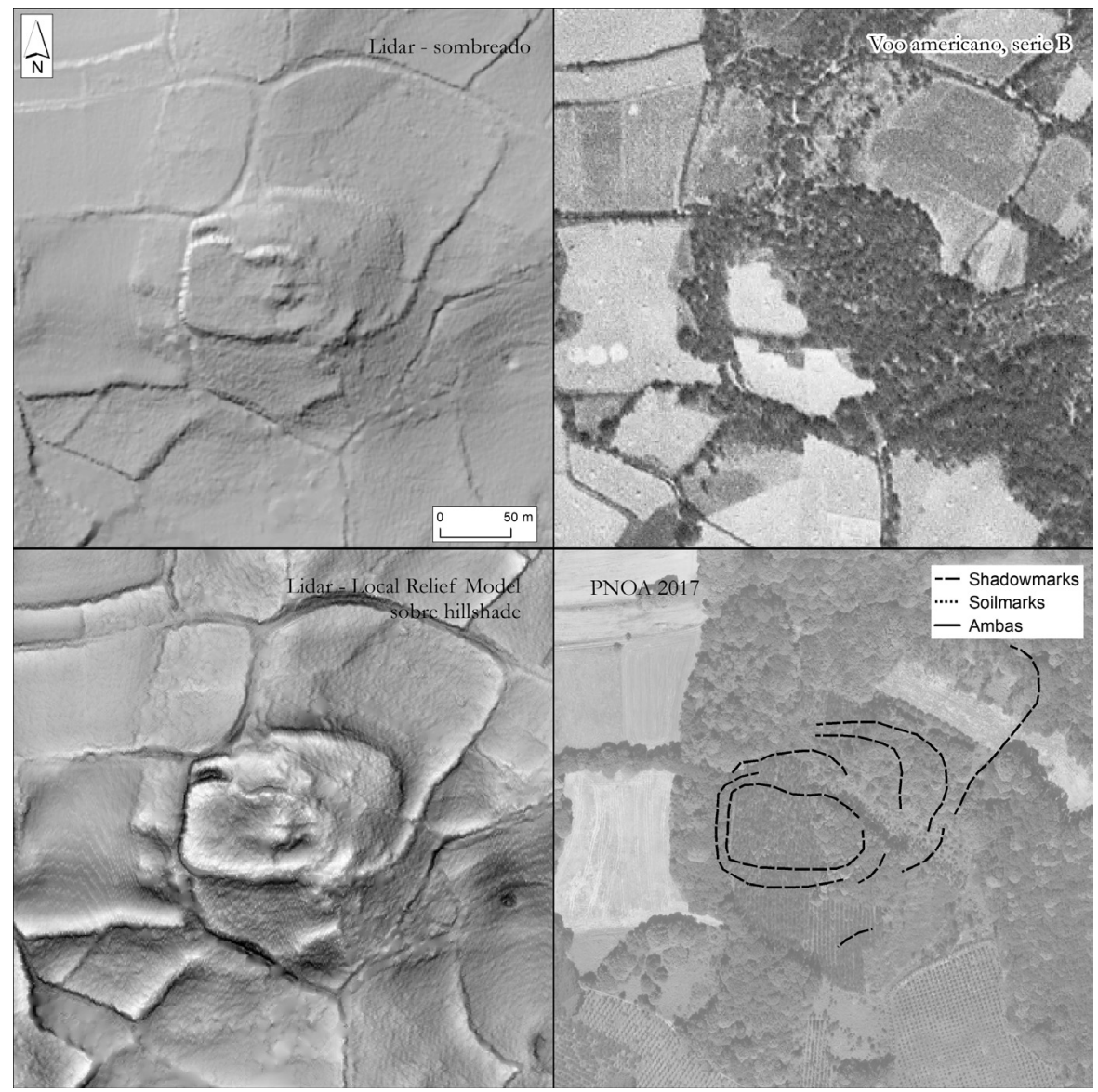

Figura 12. O Castro, As Bullas de Arriba, As Raposeiras (Santiago de Vilasantar, Vilasantar).

permite suxerir a existencia dun recinto circular duns $110 \mathrm{~m}$ de diámetro, delimitado por a lo menos un conxunto de foxo e antefoxo, e probablemente máis. Malia que é imposible descartar que sexa un castro, o emprazamento nunha zona relativamente chaira e a forma ben circular que ten suxiren se cadra algún outro tipo de recinto, que non difire moito formalmente de, por exemplo, os chamados recintos de foxos da Prehistoria Recente, ben coñecidos noutras partes da Península ${ }^{28}$ ou

\footnotetext{
${ }^{28}$ José Enrique MÁrquez Romero e Víctor Jiménez Laimez, Recintos de Fosos: Genealogía y Significado de Una Tradición En La Prehistoria Del Suroeste de La Península Ibérica (IV-III Milenios AC), Málaga, Universidad de Málaga, 2010; Germán Delibes de CASTRo, Marcos GarCía GARCía, Julio DEL Olmo Martín, e Jorge de Santiago Pardo, Recintos de Fosos Calcolíticos Del Valle Medio Del Duero: Arqueología Aérea y Espacial, Valladolid, Universidad de Valladolid, 2014.
} 


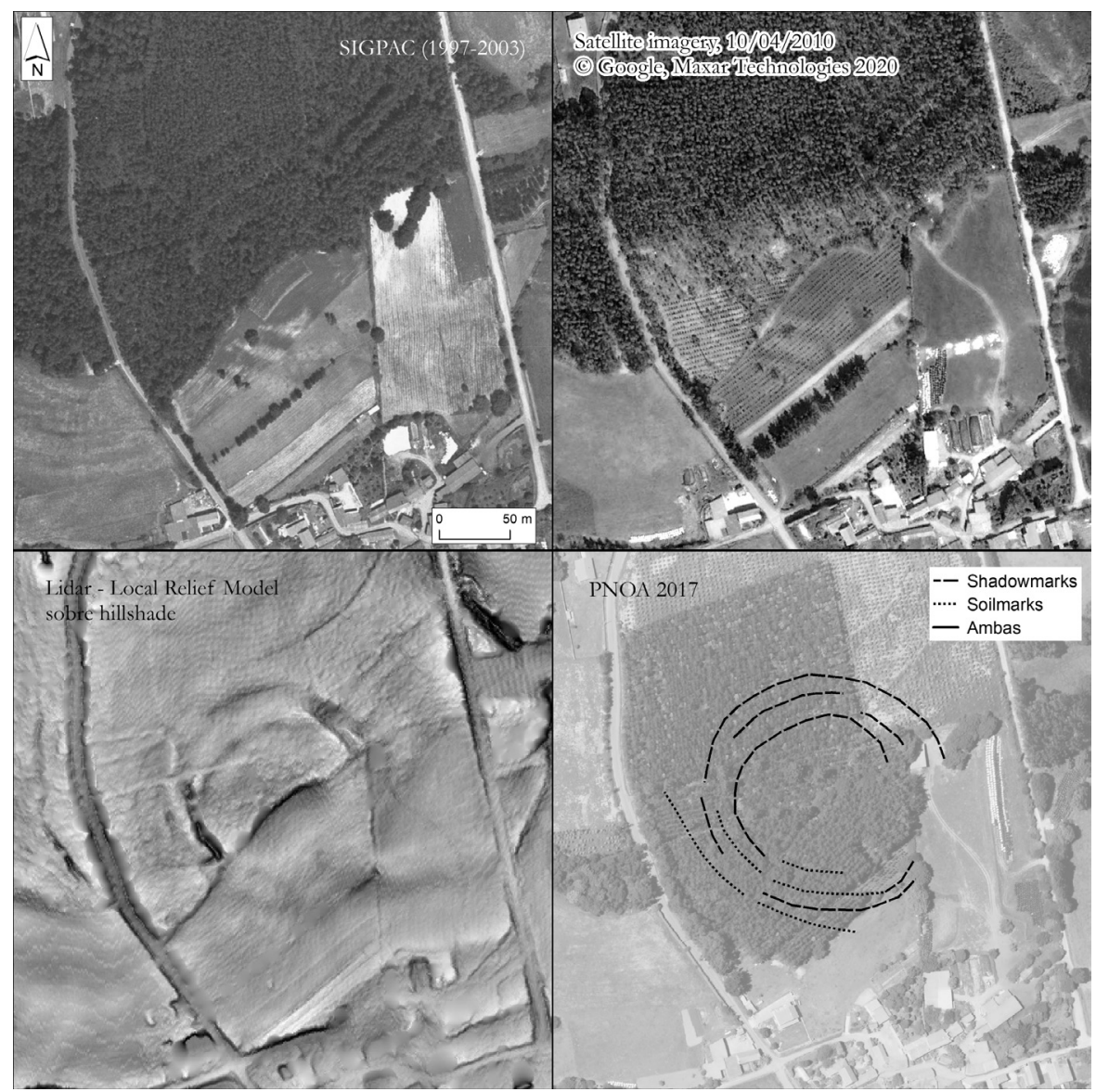

Figura 13. Recinto de Vilaboil (Sta. María de Castrofeito, O Pino).

doutros recintos circulares tamén prehistóricos documentados en Galicia ${ }^{29}$, malia que este caso de O Pino ten un tamaño bastante máis grande. Por suposto, só futuros traballos de campo poderían axudar a resolver esta cuestión.

\section{Outros ELEMENTOS DE POTENCIAL INTERESE}

Para rematar, cumpre facer referencia a outros elementos de interese que foron atopados. Trátase duns poucos casos nos que, en espazos próximos a un

\footnotetext{
29 Diego Piay Augusto, Juan Antonio Cano Pan e Juan Naveiro LóPez, "La Construcción Anular y el Enclos de Ventosiños (Coeses, Lugo). Estudio preliminar de un conjunto del Bronce Final", Zephyrus, 76 (2015), páxs. 57-76.
} 


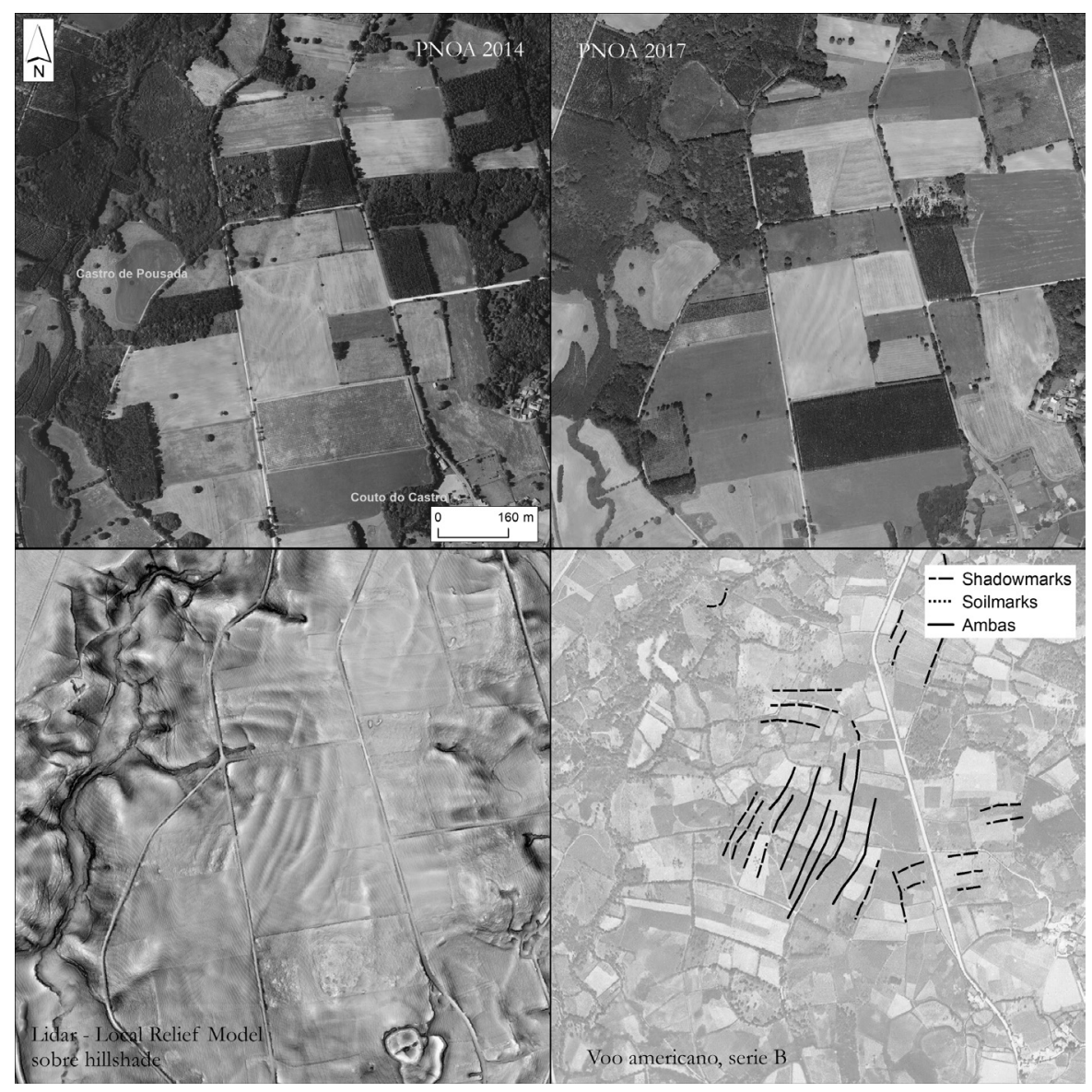

Figura 14. Indicios na área arredor dos sitios Castro de Pousada e Couto do Castro (parroquias de Castro e Cumbraos, Mesía).

ou varios castros, o Lidar amosa algunhas anomalías topográficas estrañas, que non corresponden a ningunha tipoloxía de elemento para nós coñecida pero que tampouco teñen correspondencia co parcelario actual ou o visible nas imaxes do voo americano. O mellor exemplo é, se cadra, a área arredor dos sitios Castro de Pousada e Couto do Castro (parroquias de Castro e Cumbraos, Mesía). Este espazo resulta de entrada un pouco confuso, porque a documentación manexada indica a existencia deses dous castros (e un terceiro, Castro das Rodas, un pouco ao norte da zona representada na figura 14). Porén, o lugar onde se indica a situación do primeiro deles é bastante ambiguo e os indicios son pouco concluíntes.

Pero o máis interesante é o conxunto de anomalías topográficas en forma de cómaros paralelos que son moi evidentes a través do Lidar, e tamén algúns 
deles nas ortoimaxes do PNOA de 2010 é 2017. Unha posible interpretación é que sexan parte do conxunto defensivo orixinal dese Castro de Pousada, se é que tal existiu. O problema é que, de ser certo, estaríamos ante un asentamento realmente excepcional pola súa complexidade morfolóxica, especialmente para a zona na que se localiza (estaríamos falando de ata 7 foxos e antefoxos, nunha extensión aproximada de 25 ha.). Adicionalmente, o conxunto non remata de pechar unha zona ben acoutada, o que tamén podería ser un problema de preservación. Se cadra outras interpretacións poderían ser máis axeitadas. Sen dúbida, este sitio é un dos máis interesantes dos que foron identificados e pagaría moito a pena desenvolver un traballo de campo específico. Anomalías semellantes foron tamén detectadas noutros sitios, coma na contorna do Castro de Paradela (San Paio de Paradela, Toques), en Fraga dos Frades (San Xulián de Cumbraos, Sobrado) ou non lonxe do castro da Aurela - castro de Ares (Sta. María da Capela, Toques).

\section{VERIFICACIÓN DOS RESULTADOS}

Vimos de presentar un conxunto diverso de casos, algúns deles poden semellar máis convincentes ca outros, pero en calquera caso trátase sempre de indicios documentados en forma de anomalías topográficas ou de textura e cores nas fotos aéreas, e para ningún deles temos unha evidencia directa de a que tipo de elementos poderían corresponderse. Afortunadamente, puidemos documentar un caso no que si é posible obter unha fonte de información independente que nos permite contrastar a correspondencia destes indicios con estruturas específicas.

Trátase do sitio de A Aurela do Castro (San Pedro de Doade, Lalín), un castro no que se veñen realizando traballos de escavación arqueolóxica nos últimos $\operatorname{anos}^{30}$. Este sitio é un dos varios nos que puidemos identificar indicios de posibles foxos no exterior do castro, en concreto cara ao Sur (figura 15). Segundo se indica na páxina web do proxecto de escavación do sitio, nos anos 2018 e 2019 realizouse cadansúa sondaxe en dous puntos coincidentes con algunhas destas marcas (sinalados cunha estrela na figura 15), e ámbalas dúas ofreceron evidencias claras de foxos de grande magnitude: un, o máis exterior, de " $8 \mathrm{~m}$ de ancho e 5,30 m de fondo" e o outro de 3 metros de profundidade (figura 16) ${ }^{31}$.

É importante dicir que os propios responsables da escavación tamén teñen reparado nesta evidencia e así, na devandita web, ofrecen unha interpretación non

\footnotetext{
${ }^{30}$ Vanesa Trevín Pita (ed.), O Castro de Doade. Unha fortificación da Idade de Ferro no corazón do Deza, Lalín, A Formiga Rabicha, 2019. Ver tamén <www.castrodedoade.com>

31 "O sistema defensivo", Castro de Doade [en liña], dispoñible en $<$ http://www.castrodedoade.com/osistema-defensivo/> [Consulta: 20/04/2020].
} 


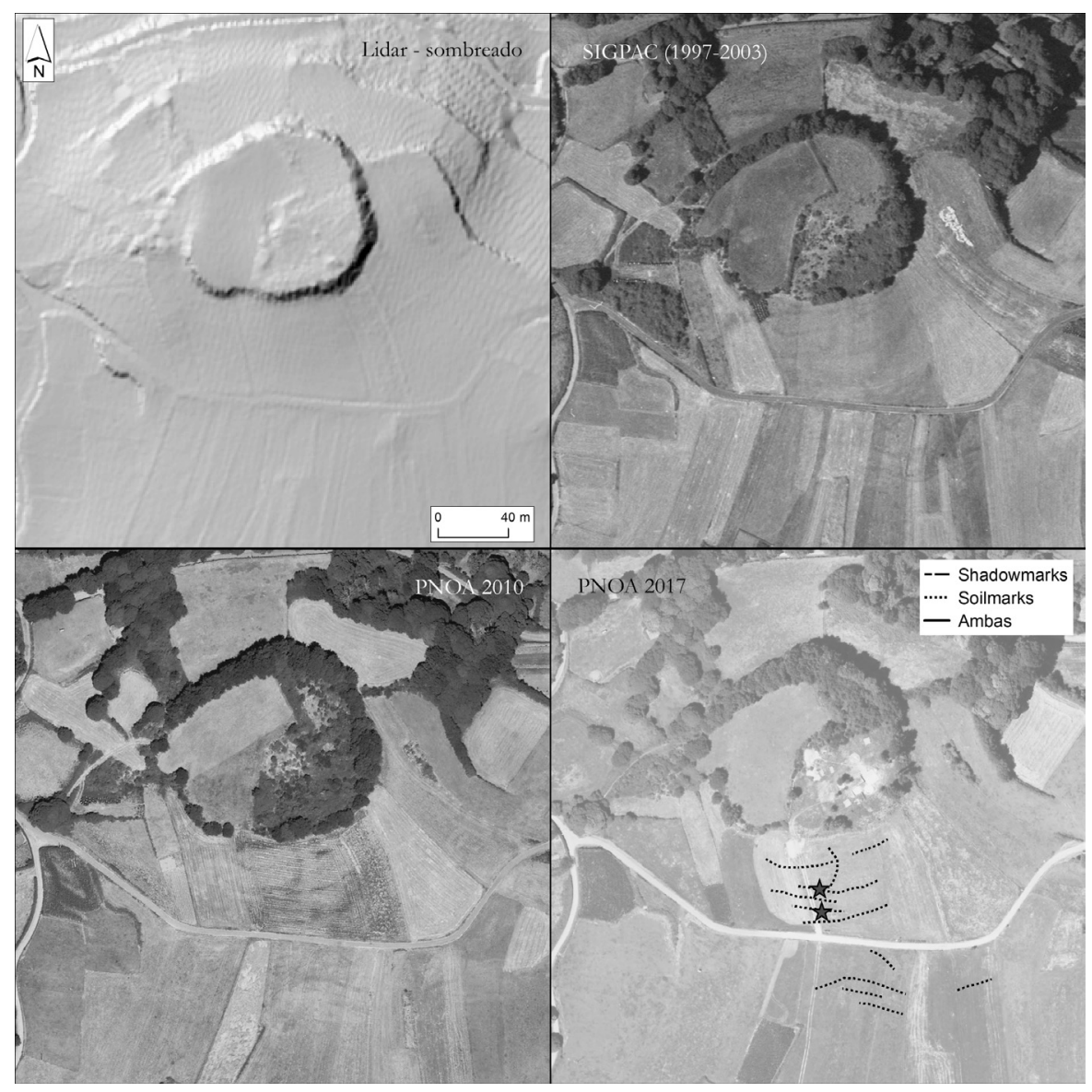

Figura 15. A Aurela do Castro (San Pedro de Doade, Lalín). Indicios de estruturas soterradas e localización de dúas das sondaxes realizadas nos últimos anos.

moi diferente da nosa (máis completa, iso si), mediante unha imaxe que semella unha ortofoto producida con drone.

\section{DiSCUSIÓN E VALORACIÓN}

Un aspecto rechamante dos resultados é a desigual distribución dos elementos documentados dentro da zona de traballo (figura 1). Así, a simple vista apréciase unha máis grande densidade de achados no sector en torno ás comarcas de Ordes - Arzúa. As razóns que explican isto son de dous tipos. Por unha banda, neste sector era onde tiñamos menos sitios identificados ao inicio do traballo e por iso a nosa revisión foi máis intensa. Para os sectores de Bergantiños - A 




Figura 16. A Aurela do Castro (San Pedro de Doade, Lalín). Fotografías das sondaxes indicadas na figura anterior (tiradas de www.castrodedoade.com).

Coruña, Santiago - Tabeirós - Deza, e Terra de Melide contabamos xa con datos máis detallados procedentes de traballos de campo anteriores, o que nos permitiu facer unha busca menos intensiva neles. Pero, por outra banda, as condicións de uso do solo neste sector son tamén máis propicias para este tipo de documentación. A razón esencial é a máis ampla extensión dos terreos de cultivo e a menor ocupación de monte baixo ou forestal. En efecto, o tipo de evidencia que documentamos só é visible, de forma xeral, en terreos de cultivo ou como moito de prados, xa que son os únicos que permiten apreciar con claridade diferenzas na profundidade ou humidade do solo. Pero, amais diso, as zonas máis intensamente cultivadas teñen producido tamén unha destrución máis intensa de elementos arqueolóxicos, e a meirande parte do que con esta metodoloxía se documenta son precisamente elementos desmantelados.

A boa correspondencia dos resultados coa maior presencia de terras cultivadas apréciase con claridade na figura 17: segundo descende a porcentaxe de terreo dedicada ao cultivo en cada comarca, vai descendendo de forma case paralela a cantidade de sitios con indicios identificados. De feito, a correlación entre ambas variables é bastante elevada $(\mathrm{r}=0.6796)$, o que reforza a impresión visual tirada do gráfico. Cómpre indicar que as comarcas que só entran de forma moi parcial na zona de traballo foron agrupadas baixo a categoría Outras.

\section{CONCLUSións E PERSPeCtivas}

O traballo aquí presentado constitúe un bo exemplo da potencialidade das estratexias de detección remota nun contexto, coma o galego, en principio non 


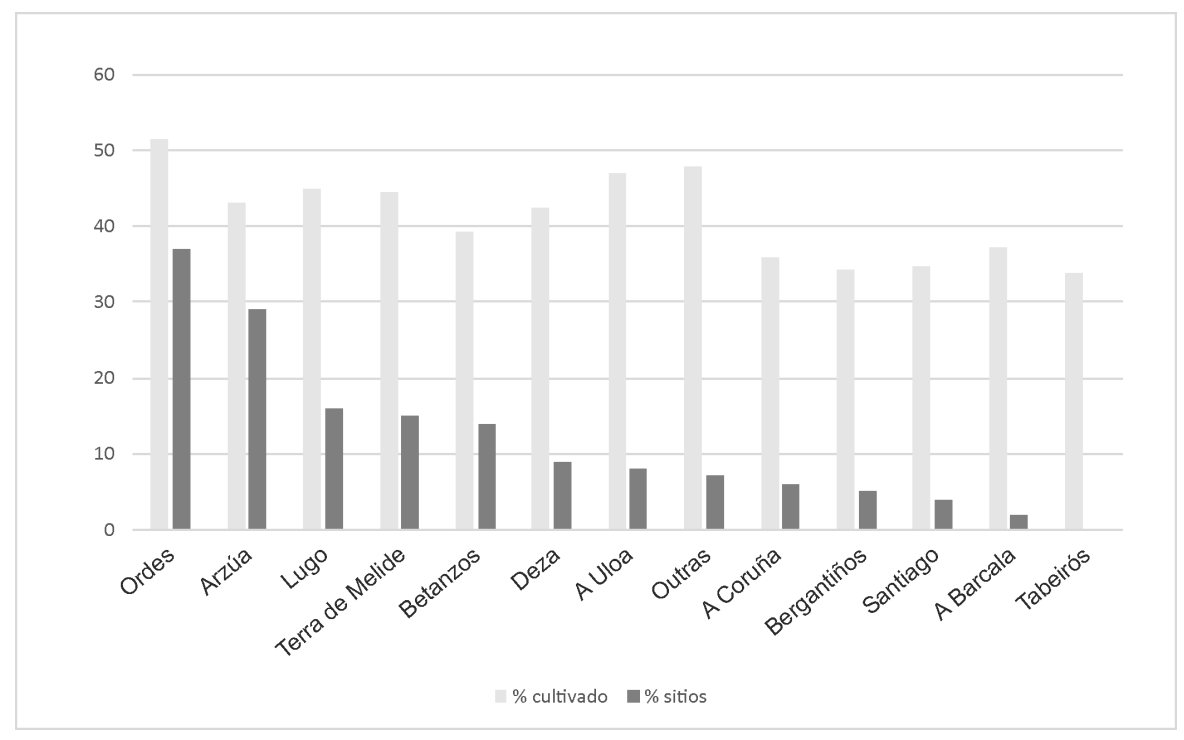

Figura 17. Relación entre a porcentaxe de terras cultivadas e a porcentaxe de sitios con indicios descubertos en cada comarca.

moi propicio para iso. O feito de ter baseado a totalidade dos elementos descubertos no emprego exclusivo de fontes de datos xeoespaciais de tipo xenérico e de acceso público non fai senón incrementar esa potencialidade. Certamente, a planificación e execución de tomas de datos especificamente orientadas á documentación arqueolóxica debería de aportar unha cantidade e variedade de evidencia aínda máis grande. Como xa foi comentado, as condicións de captura das imaxes aéreas son un factor moi influínte na utilidade dos resultados obtidos: cuestións coma a época do ano, o momento do día, as condicións de iluminación ou a altura e posición dos voos exercen unha enorme influencia na capacidade de identificar ou non indicios no terreo. A crecente dispoñibilidade de novas plataformas (coma os drones) e de novos sensores (coma cámaras térmicas ou multiespectrais) non fai senón incrementar as posibilidades de obter indicios en espazos en principio pouco aptos. Múltiples experiencias recentes en lugares xeográficos ben diversos confirman a capacidade destas aproximacións ${ }^{32}$.

\footnotetext{
32 Stefano Campana, "Drones in Archaeology. State-of-the-Art and Future Perspectives", Archaeological Prospection, 24, 4 (2017), páxs. 275-96; Austin Chad Hill, Elise Jakoby Laugier e Jesse CasanA, "Archaeological Remote Sensing Using Multi-Temporal, Drone-Acquired Thermal and Near Infrared (NIR) Imagery: A Case Study at the Enfield Shaker Village, New Hampshire”, Remote Sensing, 12, 4 (2020); José Ángel Salgado Carmona, Elia Quirós, Victorino Mayoral e Cristina Charro, “Assessing the Potential of Multispectral and Thermal UAV Imagery from Archaeological Sites. A Case Study from
} 
En particular, os drones estanse revelando como unha ferramenta especialmente aplicable na arqueoloxía, polo seu baixo custo, a facilidade de manexo e o estupendo axuste que ofrecen para a escala de traballo máis habitual en arqueoloxía. A bibliografía recente ofrece numerosos exemplos da súa aplicación en contextos xeográficos e arqueolóxicos do máis diverso ${ }^{33}$.

Como foi dito, a achega que se pode facer mediante o emprego dunha aproximación como a aquí descrita non é máis, pero tampouco menos, que a detección dunha serie de anomalías cuxa orixe, natureza e relevancia son sempre incertos. É certo que a morfoloxía e disposición das anomalías pode ás veces favorecer unha interpretación probable, como é o caso de moitas das liñas concéntricas a recintos fortificados que con grande probabilidade poden interpretarse como indicios de foxos. Pero noutros moitos casos as interpretacións son incertas e ate difíciles. Como é ben sabido, unha fase consecuente deste tipo de aproximación é frecuentemente a obtención de novas evidencias directas no terreo (groundtruthing), ben sexa mediante outras formas de detección non invasiva (como a prospección xeofísica, que permite identificar anomalías doutra natureza), ben mediante a prospección superficial convencional, a apertura de sondaxes ou a escavación. Porén non sería xusto restrinxir a utilidade desta forma de teledetección unicamente a un traballo previo á escavación: a prospección e a detección remota son unha forma de enriquecer a nosa perspectiva sobre os sitios e paisaxes arqueolóxicos, de fornecer unha ollada que transcenda os límites espaciais convencionais asumidos para estes e de empezar a entender a paisaxe coma un "archaeological continuum", se o traballo adquire a escala axeitada ${ }^{34}$.

Como tratou de mostrarse neste traballo, as contribucións que este tipo de aproximación poden facer son de diverso tipo. Por unha banda, a máis inmediata, permiten a identificación ás veces de novos sitios, ou sitios potenciais, que engadir aos xa coñecidos, incluso en zonas amplamente prospectadas e recoñe-

the Iron Age Hillfort of Villasviejas Del Tamuja (Cáceres, Spain)", Journal of Archaeological Science: Reports, 31 (2020), 102312; Christopher Brooke e Ben ClutTerbuck, "Mapping Heterogeneous Buried Archaeological Features Using Multisensor Data from Unmanned Aerial Vehicles", Remote Sensing, 12 , 1, 41 (2020), páxs. 1-31; Katherine James, Caroline J. Nichol, Tom Wade, Dave Cowley, Simon Gibson Poole, Andrew Gray e Jack Gillespie, "Thermal and Multispectral Remote Sensing for the Detection and Analysis of Archaeologically Induced Crop Stress at a UK Site”, Drones, 4, 4 (2020).

33 Juan Ángel Ruiz Sabina, David Gallego Valle, Cristina Peña Ruiz, Jesús Manuel Molero García e Antonio Gómez LagunA, "Aerial Photogrammetry by Drone in Archaeological Sites with Large Structures. Methodological Approach and Practical Application in the Medieval Castles of Campo de Montiel", Virtual Archaeology Review, 6, 13 (2015), páxs. 5-19; Catriel Greco, "Photogrammetric Survey with UAV of Strategic Villages of Yocavil (Catamarca, Argentina)", en Alina Álvarez Larrain e Catriel Greco (eds.), Political Landscapes of the Late Intermediate Period in the Southern Andes, New York, Springer, 2018, páxs. 35-60.

${ }^{34}$ Stefano Campana, Mapping the Archaeological Continuum. Filling "Empty" Mediterranean Landscapes, New York, Springer, 2018. 
cidas arqueolóxicamente. Por outra banda, posibilitan facer unha caracterización máis ampla, en ocasións moito máis, de sitios xa coñecidos, recoñecendo as formas concretas do alcance da transformación da paisaxe ao longo da prehistoria. Malia que neste caso, e pola propia orixe do traballo que aquí se presentou, os elementos identificados teñen que ver con sitios da Idade do Ferro, non hai razóns para pensar que estas metodoloxías non poidan tamén achegar datos doutros tipos e cronoloxías de sitios. Dalgunha forma, a evidencia está aí á espera de que sexamos quen de recoñecela.

\section{BIBLIOGRAFÍA}

Brooke, Christopher, e Clutterbuck, Ben, "Mapping Heterogeneous Buried Archaeological Features Using Multisensor Data from Unmanned Aerial Vehicles", Remote Sensing, 12, 1, 41 (2020), páxs. 1-31.

Campana, Stefano, "Drones in Archaeology. State-of-the-Art and Future Perspectives", Archaeological Prospection, 24, 4 (2017), páxs. 275-96.

Campana, Stefano, Mapping the Archaeological Continuum. Filling "Empty” Mediterranean Landscapes, New York, Springer, 2018.

Costa-García, José Manuel, “Asentamientos militares romanos en el Norte Peninsular: aportes de la fotografía aérea histórica, la fotografía satelital y el LiDAR aéreo", Férvedes, 8 (2015), páxs. 35-44.

Costa-García, José; Fonte, João, e Gago, Manuel, "The Reassessment of the Roman Military Presence in Galicia and Northern Portugal through Digital Tools: Archaeological Diversity and Historical Problems", Mediterranean Archaeology and Archaeometry, 19 (2019), páxs. 17-49.

Cowley, David; Ferguson, Lesley, and Williams, Allan, "The Aerial Reconnaissance Archives: A Global Aerial Photographic Collection", en W. Hanson e I. Oltean (eds.), Archaeology from Historical Aerial and Satellite Archives, New York, Springer, 2013, páxs. 13-30.

Currás Refojos, Brais, Las sociedades de los castros entre la Edad del Hierro y la dominación de Roma: estudio del paisaje del Baixo Miño, Madrid, CSIC, 2019 (Biblioteca Praehistorica Hispana, 35).

Delibes de Castro, Germán; García García, Marcos; Olmo Martín, Julio del, e Santiago Pardo, Jorge de, Recintos de Fosos Calcolíticos Del Valle Medio Del Duero: Arqueología Aérea y Espacial, Valladolid, Universidad de Valladolid, 2014.

Greco, Catriel, "Photogrammetric Survey with UAV of Strategic Villages of Yocavil (Catamarca, Argentina)", en Alina Álvarez Larrain e Catriel Greco (eds.), Political Landscapes of the Late Intermediate Period in the Southern Andes, New York, Springer, 2018, páxs. 35-60.

Hesse, Ralf, "LiDAR-Derived Local Relief Models - a New Tool for Archaeological Prospection”, Archaeological Prospection, 17, 2 (2010), páxs. 67-72.

Hesse, Ralf, "The Changing Picture of Archaeological Landscapes: Lidar Prospection over Very Large Areas as Part of a Cultural Heritage Strategy", en Rachel Opitz e Dave Cowley 
(eds.), Interpreting Archaeological Topography. Airborne Laser Scanning, 3D Data and Ground Observation, Oxford, Oxbow Books, 2013, páxs. 171-183.

Hill, Austin Chad; Laugier, Elise Jakoby, e Casana, Jesse, “Archaeological Remote Sensing Using Multi-Temporal, Drone-Acquired Thermal and Near Infrared (NIR) Imagery: A Case Study at the Enfield Shaker Village, New Hampshire", Remote Sensing, 12, 4 (2020).

James, Katherine; Nichol, Caroline J.; Wade, Tom; Cowley, Dave; Gibson Poole, Simon; Gray, Andrew, e Gillespie, Jack, "Thermal and Multispectral Remote Sensing for the Detection and Analysis of Archaeologically Induced Crop Stress at a UK Site", Drones, 4, 4 (2020).

Kokalj, Žiga, e Hesse, Ralf, Airborne Laser Scanning Raster Data Visualization. A Guide to Good Practice, Ljubljana, Založba ZRC, 2017.

Kokalj, Žiga, e Somrak, Maja, "Why Not a Single Image? Combining Visualizations to Facilitate Fieldwork and On-Screen Mapping”, Remote Sensing 11, 7 (2019).

Márquez Romero, José Enrique, e Jiménez Jáimez, Víctor, Recintos de Fosos: Genealogía y Significado de Una Tradición En La Prehistoria Del Suroeste de La Península Ibérica (IV-III Milenios AC), Málaga, Universidad de Málaga, 2010.

Musson, Chris; Palmer, Rog, e Campana, Stefano, Flights Into The Past. Aerial Photography, Photo Interpretation and Mapping for Archaeology. Aerial Archaeology Research Group, Heidelberg University Library, 2013 (Occasional Publication No. 4).

Orejas Saco del Valle, Almudena, Del Marco Geográfico a la Arqueología del Paisaje. La aportación de la Fotografia Aérea, Madrid, CSIC, 1995 (Monografías, 15).

Parcero-Oubiña, César, “Aerial Archaeology in Spain: Out of the Closet?”, AARG News, the Newsletter of the Aerial Archaeology Research Group, 52 (2016), páxs. 12-14.

Parcero-Oubiña, César e Nión-Álvarez, Samuel. "Forms of settlement inequality over space. A GIS-based method for measuring differences among settlements", Journal of Archaeological Science: Reports, 35, 102739 (2021).

Piay Augusto, Diego; Cano Pan, Juan Antonio, e Naveiro López, Juan, "La construcción anular y el enclos de Ventosiños (Coeses, Lugo). Estudio preliminar de un conjunto del Bronce Final", Zephyrus, 76 (2015), páxs. 57-76.

Ruiz Sabina, Juan Ángel; Gallego Valle, David; Peña Ruiz, Cristina; Molero García, Jesús Manuel, e Gómez Laguna, Antonio, “Aerial Photogrammetry by Drone in Archaeological Sites with Large Structures. Methodological Approach and Practical Application in the Medieval Castles of Campo de Montiel." Virtual Archaeology Review, 6, 13 (2015), páxs. 5-19.

Salgado Carmona, José Ángel, Quirós, Elia, Mayoral, Victorino e Charro, Cristina, “Assessing the Potential of Multispectral and Thermal UAV Imagery from Archaeological Sites. A Case Study from the Iron Age Hillfort of Villasviejas Del Tamuja (Cáceres, Spain)", Journal of Archaeological Science: Reports, 31 (2020), 102312.

Sánchez-Palencia, Francisco Javier, e Orejas Saco del Valle, Almudena, "Fotointerpretación Arqueológica: El Estudio Del Territorio", en Assució Vila (ed.), Arqueología, Madrid, CSIC, 1991 (Nuevas Tendencias, 19), páxs. 1-22.

Sánchez Pardo, José Carlos, e Fumadó Ortega, Iván, “Aerial Archaeology in Spain: Historiography and Expectations", en Stefano Campana e Maurizio Forte (eds.), From Space to 
HABELOS, HAINOS. DETECCIÓN REMOTA DE INDICIOS ARQUEOLÓXICOS MEDIANTE FOTOGRAFÍA AÉREA E LIDAR EN CASTROS DE GALICIA

Place. 2nd International Conference on Remote Sensing in Archaeology, Oxford, BAR International Series, 2006, páxs. 65-71.

Stichelbaut, Birger; Bourgeois, Jean; Saunders, Nick, e Chielens, Piet, Images of Conflict: Military Aerial Photography and Archaeology, Newcastle-upon-Tyne, Cambridge Scholars Publishing, 2009.

Trevín Pita, Vanesa (ed.), O Castro de Doade. Unha fortificación da Idade de Ferro no corazón do Deza, Lalín, A Formiga Rabicha, 2019.

Wilson, David Raoul, Air Photo Interpretation for Archaeologists, London, Batsford, 1982. 
